\title{
Two-Year Data from a Long-Term Phase IV Study of Recombinant Human Growth Hormone in Short Children Born Small for Gestational Age
}

\author{
Hans-Peter Schwarz • Mieczysław Walczak • Dorota Birkholz-Walerzak • \\ Mieczyslaw Szalecki · Michaela Nanu · Heike Woehling • \\ Ellen Schuck
}

Received: December 14, 2015 / Published online: February 17, 2016

(C) The Author(s) 2016. This article is published with open access at Springerlink.com

\section{ABSTRACT}

Introduction: This ongoing, prospective, open-label, non-comparative, multicenter phase IV study is evaluating the safety and efficacy of recombinant human growth hormone (rhGH; Omnitrope ${ }^{\circledR}$, Sandoz GmbH) in short children born small for gestational age (SGA). Here we report data from patients who have completed 2 years' treatment.

Electronic supplementary material The online version of this article (doi:10.1007/s12325-016-0301-1) contains supplementary material, which is available to authorized users.

Hans-PeterSchwarz

Department of Endocrinology, von Haunersches Kinderspital, University Hospital Munich, Munich, Germany

M. Walczak

Department of Paediatric Endocrinology and Diabetology, Pomeranian Medical University, Szczecin, Poland

D. Birkholz-Walerzak

Department of Diabetology and Endocrinology,

Medical University of Gdansk, Gdańsk, Poland

\section{Szalecki}

Clinic of Endocrinology and Diabetology, Children's Memorial Health Institute, Warsaw, Poland
Methods: Eligibility criteria included prepubertal children born SGA with growth disturbances defined as current height standard deviation score (HSDS) $<-2.5$ and parental adjusted $\mathrm{SDS}<-1$; birth weight and/or length $<-2$ SDS; and failure of catch-up growth [height velocity (HV) $\mathrm{SDS}<0$ during the last year] by 4 years of age or later. The primary study objective is to assess the long-term effect of Omnitrope treatment on the development of diabetes in short children born SGA. Secondary objectives include evaluation of efficacy, incidence and severity of adverse events (AEs), occurrence of

\section{Szalecki}

Faculty of Medicine and Health Sciences UJK, Kielce, Poland

\section{Nanu}

"Alfred Russescu" Institute for Mother and Child

Care, Bucharest, Romania

H. Woehling · E. Schuck ( $\square)$

HEXAL AG, Holzkirchen, Germany

e-mail: ellen.schuck@sandoz.com 
malignancies during treatment, and detection of anti-rhGH antibodies during treatment.

Results: In total, 278 children have been enrolled and received study medication; 249 have completed 2 years of treatment. No child has developed diabetes mellitus during the first 2 years; no fasting glucose or 2-h oral glucose tolerance test value exceeded the pre-defined limits of $>126$ or $>200 \mathrm{mg} / \mathrm{dL}$, respectively. No adverse alterations in body mass were noted. Treatment-emergent AEs were experienced by 211 (76.2\%) children; most of these were of mild-to-moderate intensity (99.3\%) and considered unrelated to study medication (97.6\%). Treatment with Omnitrope was effective; mean HSDS was -3.39 at baseline, -2.57 at 1 year and -2.15 at 2 years of treatment. Mean HVSDS (peak-centered) also improved, from -2.13 at baseline to +4.16 at 1 year and +2.23 at 2 years.

Conclusion: In this second interim analysis, short children born SGA were safely and effectively treated with rhGH (Omnitrope), and 2 years' treatment had no major adverse impact on carbohydrate metabolism or body mass.

Funding: Sandoz.

Keywords: Endocrinology; Omnitrope; Recombinant human growth hormone; Small for gestational age; Somatropin

\section{INTRODUCTION}

Omnitrope $^{\circledR}$ (Sandoz) is a recombinant human growth hormone (rhGH) approved by the European Medicines Agency in 2006; approval was granted via the biosimilar regulatory pathway, on the basis of comparable quality, safety, and efficacy to the reference product (Genotropin $^{\circledR}$, Pfizer) [1]. Omnitrope is licensed for use to treat growth disturbances in the following pediatric indications: growth hormone deficiency (GHD), Turner syndrome, chronic renal insufficiency, Prader-Willi syndrome, and short children born small for gestational age (SGA) [2].

Depending on the definition used, up to $10 \%$ of all live births each year are described as SGA [3]. Most children born SGA achieve appropriate catch-up growth by the age of 2-3 years, although approximately $10 \%$ do not; these children are at heightened risk of short stature in adulthood $[3,4]$. In addition to short stature, SGA infants may be predisposed to altered body composition and (in adult life) hypertension and cardiovascular disease [4-7]. Data from epidemiological studies indicate that children born SGA are also at increased risk of insulin resistance and type 2 diabetes in adulthood [8, 9]. rhGH therapy has been shown to induce transient resistance to the actions of insulin in children; therefore, concerns exist over the diabetogenic potential of rhGH therapy in children born SGA.

There are only limited data on the long-term use of rhGH in SGA children and the impact of treatment on diabetes in this population. This ongoing, long-term, phase IV, multicenter study with Omnitrope is the largest prospective clinical study so far conducted of rhGH in SGA patients [10]. In this paper, data are reported for patients who have completed 2 years of treatment.

\section{METHODS}

\section{Study Design and Patients}

The study design has been reported in detail previously [10]. Briefly, this is an ongoing, prospective, open-label, non-comparative, 
multicenter, phase IV study. Key inclusion criteria are as follows: prepubertal (Tanner stage I) children born SGA with growth disturbances defined as current height standard deviation score (HSDS) $<-2.5$ and parental adjusted SDS $<-1$; birth weight and/ or length $<-2$ SDS [11]; failure of catch-up growth [height velocity (HV) SDS $<0$ during the last year] by 4 years of age or later; availability of height records between 18 months and 6 months before the start of treatment. Key exclusion criteria include onset of puberty, closed epiphyses, type 1 or 2 diabetes mellitus, fasting blood glucose $>100 \mathrm{mg} / \mathrm{dL} \quad(5.6 \mathrm{mmol} / \mathrm{L}), \quad$ and abnormal 2-h oral glucose tolerance test [OGTT; >140 mg/dL (7.8 mmol/L)].

For each participating center, an Independent Ethics Committee or Institutional Review Board reviewed and approved the study protocol, including all amendments. All procedures complied with the ethical standards of the responsible committee on human experimentation (institutional and national) and with the Helsinki Declaration of 1964, as revised in 2013. Informed consent was obtained from all patients for being included in the study.

\section{Study Objectives}

The primary study objective is to assess the long-term effect of Omnitrope treatment on the development of diabetes in short children born SGA. Secondary objectives include evaluation of efficacy through changes in height parameters, incidence and severity of adverse events (AEs), occurrence of malignancies during treatment, and detection of anti-rhGH antibodies during treatment.

\section{Study Treatment}

Patients are treated with Omnitrope $0.035 \mathrm{mg} /$ $\mathrm{kg} /$ day administered subcutaneously. If insulin-like growth factor I (IGF-I) exceeds $+2 \mathrm{SD}$ compared to references for age and pubertal status, the ratio of IGF-I to insulin-like growth factor-binding protein 3 (IGFBP-3) is taken into account. If the IGF-I/ IGFBP-3 ratio also exceeds $+2 \mathrm{SD}$, a dose reduction is recommended. The extent of the dose reduction is at the discretion of the investigator. Dose increases are only permitted based on an increase in body weight.

Treatment was discontinued after 1 year if HVSDS was below +1 , in which case the patient was classed as a non-responder. Responders continue treatment until $\mathrm{HV}<2 \mathrm{~cm} /$ year, and if confirmation is required, bone age (BA) $>14$ years (girls) or $>16$ years (boys).

\section{Timing of Study Assessments}

Height is measured in $\mathrm{cm}$ and $\mathrm{HV}$ calculated. HSDS and HVSDS (based on the relevant country-specific reference tables) are assessed at baseline and at 3-month intervals throughout the first 2 years, and every 6 months thereafter. $\mathrm{X}$-rays of the left hand and wrist are used to determine BA at baseline and once yearly thereafter.

IGF-I and IGFBP-3 are measured at screening by a central laboratory, followed by every 3 months during the first year and every 6 months thereafter. IGF-I and IGFBP-3 serum levels are categorized as low $(<-2 \mathrm{SD})$, normal, or high $(>+2 \mathrm{SD})$, compared with the normal ranges for age and sex [12]. Fasting plasma glucose, insulin levels, and glycated hemoglobin $\left(\mathrm{HbA}_{1 \mathrm{c}}\right)$ are measured at baseline, 
6 months, 12 months, and annually thereafter. OGTTs are conducted at the same time points. All AEs are registered at each visit.

Antibodies to GH were measured centrally using a validated radio-binding assay for non-neutralizing anti-GH antibodies.

\section{Patient Populations and Statistical Analyses}

The intention-to-treat population consisted of all subjects enrolled in the study who received at least one dose of study medication. The safety population comprised all patients who received at least one dose of study medication and had at least one post-baseline safety assessment.

The current analysis includes data from baseline up to the 2-year visit. Analyses were performed using SAS Version 9.1.3 or later (SAS Institute Inc., Cary, NC, USA). Descriptive statistics were used to evaluate homeostasis model assessment (HOMA), quantitative insulin sensitivity check index (QUICKI), IGF-I, IGFBP-3, and SDS for IGF-I and IGFBP-3. $P$ values were calculated using paired $t$ tests, with statistical significance defined as $P<0.05$.

\section{RESULTS}

\section{Patients}

Patients have been recruited and treated at 32 centers in 7 countries (Poland, Romania, Hungary, Czech Republic, Germany, Belgium, Georgia). In total, 278 children (148 males, 130 females) have been enrolled and received study medication; 249 have completed 2 years of treatment. Twenty-nine children have therefore been withdrawn from the study (non-responders, $n=13$; withdrawal of consent, $n=11$; loss to follow-up, $n=3$; protocol violation, $n=1$; not taking medication, $n=1)$. Table 1 shows data on patient demographics and baseline characteristics.

\section{Impact of rhGH on Diabetes (Primary Endpoint)}

No child developed diabetes mellitus during the first 2 years; no fasting glucose or 2-h OGTT value exceeded the pre-defined limits $(>126$ or $>200 \mathrm{mg} / \mathrm{dL}$, respectively). Glucose metabolism data are summarized in Table 2; statistically significant changes (from baseline to Year 1 and Year 2) did occur, but all values remained within normal limits.

Impaired glucose tolerance (2-h glucose $>7.8<11.1 \mathrm{mmol} / \mathrm{L}$ in OGTT) was present in $8 / 269$ patients at 1 year (3.0\%) and in $6 / 249$ patients at 2 years (2.4\%). Among those patients only 1 patient had impaired glucose tolerance at both time points.

\section{Impact of rhGH on BMI}

At baseline, mean (SD) body mass index (BMI) SDS was -1.54 (1.36). BMI SDS initially decreased after start of Omnitrope treatment; at month 6 , the mean change from baseline was -0.18 [95\% confidence interval (CI) for mean difference: $-0.26,-0.04 ; P<0.0001]$. By Year 1 , the mean change from baseline in BMI SDS was -0.10 (95\% CI for mean difference: -0.17 , $-0.03 ; \quad P=0.0065) ; \quad$ by Year 2 , the mean change from baseline was 0.08 (95\% CI for mean difference: $-0.01,0.17 ; P=0.0922)$.

\section{Additional Safety Assessments}

In total, 1093 AEs were reported in 211 (76.2\%) children, most of which were mild-to-moderate in intensity (99.3\%) and unrelated to study 
Table 1 Patient demographics and baseline characteristics

\begin{tabular}{lllc}
\hline Characteristics & Male & Female & Total \\
\hline Gender, $n$ (\%) & $148(53.2)$ & $130(46.8)$ & $278(100)$ \\
Caucasian ethnicity, $n$ (\%) & $146(98.6)$ & $129(99.2)$ & $275(98.9)$ \\
Mean age (SD) at baseline (years) & $7.7(2.7)$ & $7.0(2.6)$ & $7.4(2.7)$ \\
Mean height (SD) at baseline (cm) & $112.44(14.20)$ & $108.56(13.96)$ & $110.63(14.20)$ \\
Mean height SDS (SD) at baseline & $-3.38(0.77)$ & $-3.40(0.78)$ & $-3.39(0.78)$ \\
Mean HV (SD) at baseline (cm/year) & $4.09(1.33)$ & $4.43(1.26)$ & $4.25(1.30)$ \\
Mean HVSDS (SD) at baseline ${ }^{\mathrm{a}}$ & $-1.91(1.62)$ & $-1.72(1.30)$ & $-1.82(1.48)$ \\
Mean weight (SD) at baseline (kg) & $19.3(6.3)$ & $17.0(5.3)$ & $18.3(6.0)$ \\
Mean BMI SDS & $\mathrm{n} / \mathrm{a}$ & $\mathrm{n} / \mathrm{a}$ & $-1.54(1.36)$ \\
Mean (SD) birth weight SDS & $-3.2(1.3)$ & $-2.9(1.1)$ & $-3.0(1.2)$ \\
Mean (SD) birth length SDS & $-2.1(1.6)$ & $-1.6(1.6)$ & $-1.8(1.6)$ \\
Gestational age (SD) (weeks) & $38.4(2.5)$ & $38.5(2.5)$ & $38.5(2.5)$ \\
\hline
\end{tabular}

$B M I$ body mass index, $H V$ height velocity, $n / a$ not available, $S D$ standard deviation, $S D S$ standard deviation score

a Peak-centered data

treatment (97.6\%). The most commonly occurring AEs are shown in Table 3. In total, 24 drug-related AEs occurred in 17 (6.1\%) patients (hypothyroidism, $n=7$; headache, $n=3$; impaired fasting plasma glucose, $n=3$; IGF-I/IGFBP-3 increased, $\quad n=2$; thyroid-stimulating hormone increased, $n=1$; puncture site hematoma, $n=1$; scoliosis, $n=1$; upper respiratory tract infection, $n=1$; bronchitis, $n=1$; impaired glucose tolerance, $n=1$; pharyngitis, $n=1$; viral infection, $n=1$; scarlet fever, $n=1$ ). All (except one case of headache) were considered mild in severity, and none required study treatment to be permanently discontinued.

Serious AEs were reported in 22 patients (7.9\%), with only one (severe headache) suspected to be related to study treatment. There have been no reports of malignancies or deaths during the first 2 years of treatment.

Anti-rhGH antibody levels above the cut-off value were measured in 7 patients $(2.7 \%)$ at
Year 1 and in 3 patients (1.2\%) at Year 2. Positive test results were transient: only 2 $(0.8 \%)$ patients had antibodies above the cut-off value in two separate visits.

\section{Efficacy}

Omnitrope treatment was effective, as shown by various height parameters. Mean HSDS is shown in Fig. 1, and mean HVSDS in Fig. 2. Catch-up growth continued after 2 years, with a mean HVSDS of 2.23 .

Increases in both BA and height age (HA) were greater than 2 years (with HA increasing more than $\mathrm{BA}$ ), indicating ongoing true catch-up growth as a result of Omnitrope treatment. Development of BA and $\mathrm{HA}$ in comparison with chronological age (CA) between baseline and 2 years (mean ratios for overall study population) was as follows: $\triangle \mathrm{BA}$ / $\triangle \mathrm{CA} \quad$ was $1.25 \quad(P<0.001) ; \quad \Delta \mathrm{HA} / \Delta \mathrm{CA} \quad 1.34$ $(P<0.001) ; \Delta$ HA/ $\triangle$ BA $1.29(P<0.001)$. 
Table 2 Summary of glucose metabolism data

\begin{tabular}{|c|c|c|c|c|}
\hline Parameters & Visit & Mean & SD & $\begin{array}{l}\text { Mean change from } \\
\text { baseline ( } P \text { value) }\end{array}$ \\
\hline \multirow[t]{3}{*}{ 2-h OGTT $(\mathrm{mmol} / \mathrm{L})$} & Baseline & 5.28 & 1.29 & \\
\hline & Year 1 & 5.43 & 1.27 & $0.15(P=0.141)$ \\
\hline & Year 2 & 5.35 & 1.17 & $0.08(P=0.426)$ \\
\hline \multirow[t]{3}{*}{ Fasting glucose $(\mathrm{mmol} / \mathrm{L})$} & Baseline & 4.55 & 0.61 & \\
\hline & Year 1 & 4.65 & 0.56 & $0.10(P=0.009)$ \\
\hline & Year 2 & 4.69 & 0.51 & $0.17(P=0.0002)$ \\
\hline \multirow[t]{3}{*}{ Fasting insulin $(\mathrm{pmol} / \mathrm{L})$} & Baseline & 35.65 & 34.69 & \\
\hline & Year 1 & 53.68 & 35.93 & $17.22(P<0.0001)$ \\
\hline & Year 2 & 60.27 & 49.93 & $24.63(P<0.0001)$ \\
\hline \multirow[t]{3}{*}{$\mathrm{HbA}_{1 \mathrm{c}}(\%)$} & Baseline & 5.29 & 0.50 & \\
\hline & Year 1 & 5.37 & 0.51 & $0.07(P=0.005)$ \\
\hline & Year 2 & 5.37 & 0.49 & $0.08(P=0.006)$ \\
\hline \multirow[t]{3}{*}{ HOMA } & Baseline & 1.01 & 1.03 & \\
\hline & Year 1 & 1.57 & 1.11 & $0.54(P<0.0001)$ \\
\hline & Year 2 & 1.74 & 1.39 & $0.76(P<0.0001)$ \\
\hline \multirow[t]{3}{*}{ QUICKI } & Baseline & 0.42 & 0.10 & \\
\hline & Year 1 & 0.38 & 0.05 & $-0.04(P<0.0001)$ \\
\hline & Year 2 & 0.40 & 0.35 & $-0.01(P=0.536)$ \\
\hline
\end{tabular}

HbA $A_{1 c}$ glycated hemoglobin, HOMA homeostasis model assessment, OGTT oral glucose tolerance test, QUICKI quantitative insulin sensitivity check index, $S D$ standard deviation

At baseline, 52 patients had IGF-I SDS values below -2 , and only one patient had a value greater than +2 . At Year 2, IGF-I levels were available for 240 patients; of these, two patients had an SDS value below -2 and 39 patients had a value greater than +2 . Also at Year 2, IGF-I/ IGFBP-3 values were available for 238 patients; of these, two patients had an SDS value below -2 and 25 patients had a value greater than +2 . IGF-I levels increased relatively more than IGFBP-3 levels, resulting in a rising IGF-I/ IGFBP-3 ratio (Figs. 3, 4).

\section{DISCUSSION}

The primary objective of this study is to assess the effect of rhGH (Omnitrope) treatment on the development of diabetes in short children born SGA. Short children born SGA are thought to be at heightened risk of metabolic abnormalities, characterized by compensated insulin resistance without obvious abnormality of fasting or post-prandial glucose [13]. The insulin-antagonistic effects of $\mathrm{GH}$ treatment could potentially increase the risk of 
Table 3 Incidence of adverse events ( $>2 \%)$ by MedDRA preferred term and intensity

\begin{tabular}{|c|c|c|c|c|c|}
\hline \multirow[t]{2}{*}{ Preferred terms } & \multicolumn{3}{|c|}{ Intensity (number of events) } & \multirow{2}{*}{$\begin{array}{l}\text { Total number } \\
\text { of subjects }\end{array}$} & \multirow{2}{*}{$\begin{array}{l}\text { Incidence per } \\
\text { subject-year }\end{array}$} \\
\hline & Mild & Moderate & Severe & & \\
\hline Pharyngitis & 59 & 18 & 0 & $73(26.40 \%)$ & 0.137 \\
\hline Nasopharyngitis & 65 & 3 & 0 & $66(23.80 \%)$ & 0.124 \\
\hline Bronchitis & 30 & 5 & 1 & $35(12.60 \%)$ & 0.066 \\
\hline Upper respiratory tract infection & 33 & 6 & 0 & $34(12.30 \%)$ & 0.064 \\
\hline Varicella & 18 & 3 & 0 & $21(7.60 \%)$ & 0.039 \\
\hline Rhinitis & 15 & 2 & 1 & $18(6.50 \%)$ & 0.034 \\
\hline Tonsillitis & 15 & 4 & 0 & $18(6.50 \%)$ & 0.034 \\
\hline Headache & 14 & 2 & 2 & $17(6.10 \%)$ & 0.032 \\
\hline Cough & 14 & 1 & 0 & $15(5.40 \%)$ & 0.028 \\
\hline Ear infection & 15 & 0 & 0 & $15(5.40 \%)$ & 0.028 \\
\hline Hypothyroidism & 14 & 1 & 0 & $15(5.40 \%)$ & 0.028 \\
\hline Pyrexia & 13 & 1 & 0 & $14(5.10 \%)$ & 0.026 \\
\hline Urinary tract infection & 13 & 1 & 0 & $14(5.10 \%)$ & 0.026 \\
\hline Otitis media & 10 & 4 & 0 & $13(4.70 \%)$ & 0.024 \\
\hline Diarrhea & 10 & 2 & 0 & $12(4.30 \%)$ & 0.023 \\
\hline Respiratory tract infection & 10 & 1 & 0 & $11(4.00 \%)$ & 0.021 \\
\hline Rhinorrhea & 10 & 0 & 0 & $10(3.60 \%)$ & 0.019 \\
\hline Scarlet fever & 8 & 1 & 0 & $9(3.20 \%)$ & 0.017 \\
\hline Vomiting & 9 & 0 & 0 & $9(3.20 \%)$ & 0.017 \\
\hline Abdominal pain & 7 & 1 & 0 & $8(2.90 \%)$ & 0.015 \\
\hline Pneumonia & 7 & 1 & 0 & $8(2.90 \%)$ & 0.015 \\
\hline Viral infection & 8 & 1 & 0 & $8(2.90 \%)$ & 0.015 \\
\hline Acute tonsillitis & 6 & 1 & 0 & $7(2.50 \%)$ & 0.013 \\
\hline Dental caries & 6 & 1 & 0 & $7(2.50 \%)$ & 0.013 \\
\hline Influenza & 7 & 0 & 0 & $7(2.50 \%)$ & 0.013 \\
\hline Lymphadenopathy & 7 & 0 & 0 & $7(2.50 \%)$ & 0.013 \\
\hline Gastroenteritis & 6 & 0 & 0 & $6(2.20 \%)$ & 0.011 \\
\hline
\end{tabular}

developing type 2 diabetes in children born SGA. In this second interim analysis, no patients developed diabetes during 2 years of rhGH treatment. Fasting plasma glucose and stimulated glucose (OGTT) remained relatively stable over 2 years of rhGH treatment. These 2-year data are consistent with previous studies on the effects of rhGH treatment on glucose tolerance and insulin sensitivity in children born SGA [14, 15]. Our findings are also 


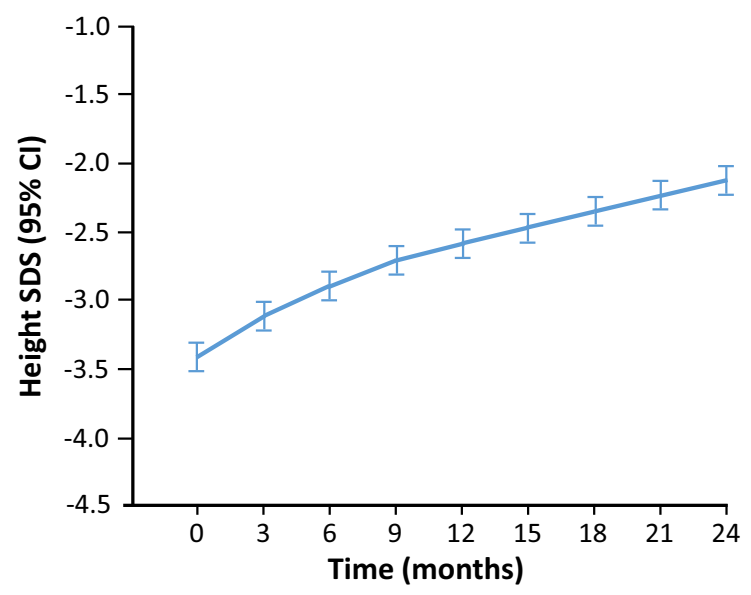

Fig. 1 Mean (95\% CI) height SDS during 2 years of treatment with Omnitrope ${ }^{\circledR}$. $C I$ confidence interval, SDS standard deviation score

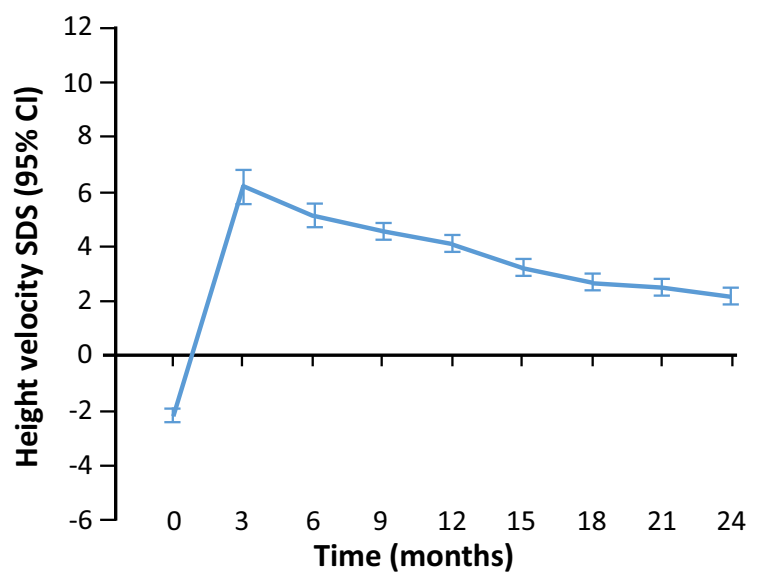

Fig. 2 Mean (95\% CI) height velocity SDS during 2 years of treatment with Omnitrope ${ }^{\circledR}$. CI confidence interval, $S D S$ standard deviation score

consistent with the previously proposed concept of a compensatory hyperinsulinemia that counters the GH-mediated increase in insulin resistance and maintains normal glucose regulation during treatment [16]. In addition, our data indicate no adverse alterations in body mass after 2 years of Omnitrope treatment; again, this is in line with other long-term studies of rhGH treatment in children born SGA [17].
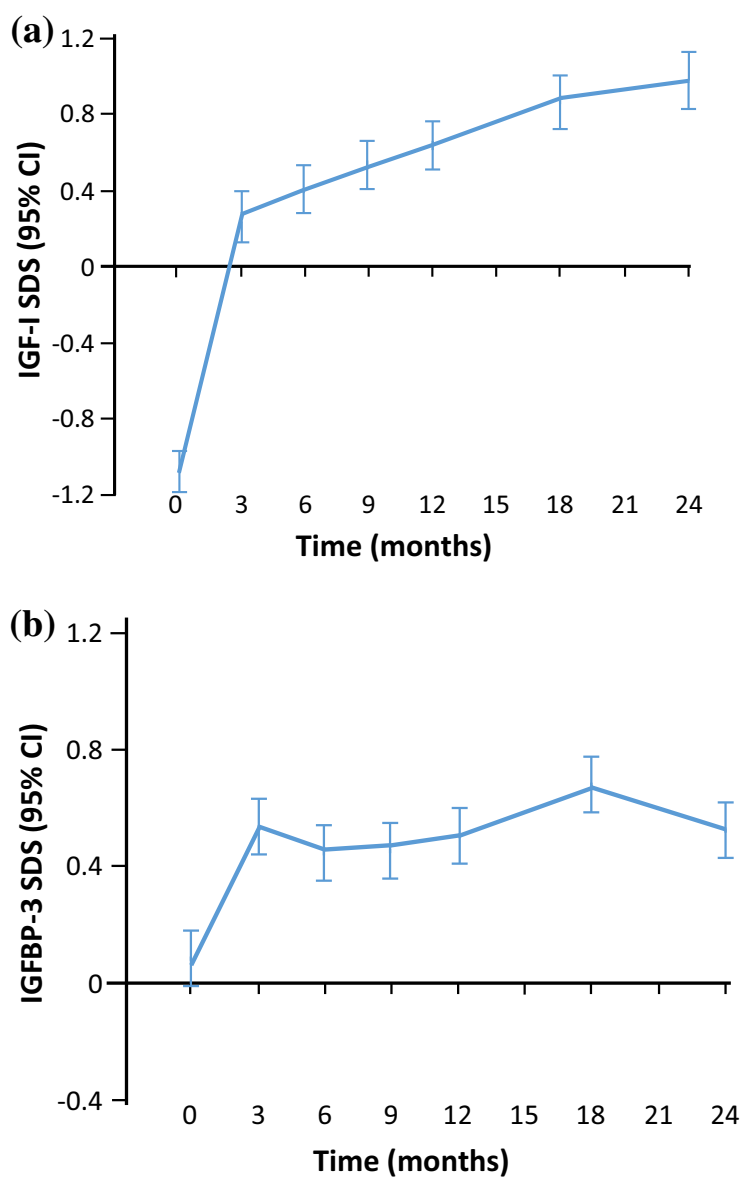

Fig. 3 Mean (95\% CI) IGF-I SDS (a) and IGFBP-3 SDS (b) during 2 years of treatment with Omnitrope ${ }^{\circledR}$. CI confidence interval, IGFBP-3 insulin-like growth factor-binding protein 3, IGF-I insulin-like growth factor I, $S D S$ standard deviation score

The safety profile of rhGH in SGA children is generally recognized as good [3], and data from this 2-year analysis support this assertion. In the 1-year interim analysis, the incidence of treatment-related hypothyroidism and headache was $2.5 \%$ and $1.1 \%$, respectively [10]; no additional cases were reported after 2 years of rhGH treatment. The incidence of anti-rhGH antibodies after 2 years of treatment was also low, consistent with findings from long-term studies with Omnitrope in children with GH deficiency [18, 19]. 


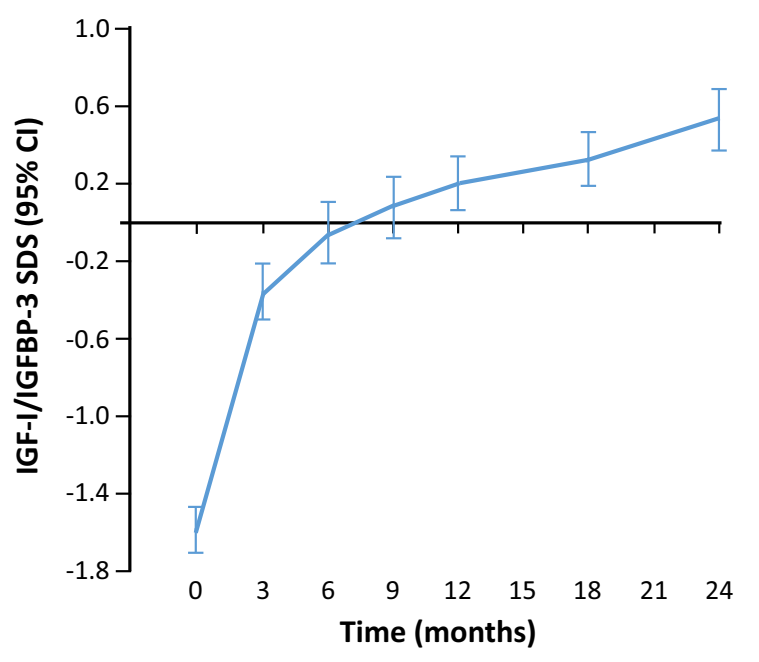

Fig. 4 Mean (95\% CI) IGF-I/IGFBP-3 ratio during 2 years of treatment with Omnitrope ${ }^{\circledR}$. CI confidence interval, IGFBP-3 insulin-like growth factor-binding protein 3, IGF-I insulin-like growth factor I, SDS standard deviation score

According to consensus guidelines, a change in HVSDS of more than +0.5 within the first year of GH treatment is considered to be a positive growth response [4]. In the present study, HVSDS had to be at least +1 after the first year of treatment for patients to be eligible to continue with therapy; therefore, all patients regarded as responders in the present study achieved a positive growth response as defined in the consensus guidelines. The improvement in growth parameters observed over 2 years' treatment with Omnitrope compares well with improvements reported in other studies of various rhGH products in short children born SGA $[13,14]$.

Possible study limitations include the lack of a control group and the age of patients when rhGH treatment was initiated (most were aged $\geq 4$ years). However, the clear treatment benefits observed in the majority of patients (increase in HV and net height gain) suggest that this is a population that is responsive to rhGH therapy.

\section{CONCLUSIONS}

At this 2-year follow-up, no patient had developed diabetes during rhGH treatment and there were no concerning or clinically relevant safety findings. Omnitrope treatment was effective, with most patients showing continuous catch-up growth after 2 years. These data, in a large international cohort of children born SGA, are consistent with a positive risk-benefit ratio for Omnitrope.

\section{ACKNOWLEDGMENTS}

The study was funded by Sandoz GmbH. The article processing charges and open access fee for this publication were funded by Sandoz $\mathrm{GmbH}$. Medical writing assistance in the preparation of this paper was provided by Tony Reardon of Spirit Medical Communications Ltd and funded by Sandoz GmbH. All named authors meet the International Committee of Medical Journal Editors (ICMJE) criteria for authorship for this manuscript, take responsibility for the integrity of the work as a whole, and have given final approval to the version to be published. All authors had full access to all relevant aggregated study data required to understand and report research findings for this study and take complete responsibility for the integrity of such data and the accuracy of the data analysis. We are grateful to all the patients and investigators at all participating centers: Germany: Prof. Dr. med Heinrich Schmidt, Dr. von Haunersche Kinderlinik, Munich; Prof. Dr. med. Gerd Horneff, Asklepios Klinik St. Augustin Zentrum für Allgemeine Padiatrie und Neonatologie, Sankt Augustin. Poland: Dr. med. Mieczyslaw Szalecki, Oddział Endokrynologiczno- Diabetologiczny 
Wojewódzki Specjalistyczny Szpital Dziecięcy im. Władysława Buszkowskiego w Kielcach, Kielce; Dr. Olgierd Pilecki, Oddział Pediatrii i Endokrynologii Wojewódzki Szpital Dziecięcy im. J. Brudzińskiego, Bydgoszcz; Dr. med. Dorota Birkholz-Walerzak, Klinika Diabetolologii i Endokrynologii Uniwersyteckie Centrum Kliniczne - Gdański Uniwersytet Medyczny, Gdańsk; Prof. Dr. hab. med. Brygida Koehler, SP Szpital Kliniczny nr 6 ŚUM w Katowicach Górnośląskie Centrum Zdrowia Dziecka Poradnia Endokrynologii Dziecięcej, Katowice; Prof. Jerzy Starzyk, Oddział Endokrynologii Dzieci i Młodzieży Uniwersytecki Szpital Dziecięcy, Krakow; Prof. Dr. hab. med. Mieczyslaw Walczak, SP Szpital Kliniczny nr 1 im. prof. T. Sokołowskiego PAM Klinika Pediatrii, Endokrynologii, Diabetologii, Szczecin; Dr. med. Katarzyna Ziora, Katedra i Klinika Pediatrii, Nefrologii i Endokrynologii Dziecięcej Samodzielny Publiczny Szpital Kliniczny $\mathrm{nr} 1 \mathrm{im}$. Prof. Stanisława Szyszko Śląskiego Uniwersytetu Medycznego, Zabrze; Prof. Ewa Malecka-Tendera, SP Szpital Kliniczny $\mathrm{nr} \quad 6 \quad$ ŚUM $\quad$ w Katowicach Górnośląskie Centrum Zdrowia Dziecka Klinika Pediatrii, Endokrynologii i Diabetologii Dziecięcej, Katowice; Prof. Dr. med. Anna Noczynska, Akademicki Szpital Kliniczny im. J. Mikulicza-Radeckiego we Wrocławiu Klinika Endokrynologii i Diabetologii Wieku Rozwojowego, Wroclaw; Prof. Renata Wasik, Niepubliczny Zakład Opieki Zdrowotnej Zawidawie Sp. z o.o, Wroclaw; Prof. Marek Niedziela, Klinika Endokrynologii i Reumatologii Dzięciecej SP ZOZ Szpital Kliniczny im. K. Jonschera UM Im. K. Marcinkowskiego, Poznan; Dr. Adam Dudek, Poradnia Endokrynologiczna Wojewódzka Przychodnia dla Dzieci Szpital Wojewodzki NR. 2, Rzeszow; Dr. Maria Szarras-Czapnik, Poradnia Endokrynologiczna
Klinika Chorób Matabolicznych, Endokrynologii i Diabetologii, Instytut "Pomnik-Centrum Zdrowia Dziecka", Warszawa; Dr. Maciej Hilczer, Klinika Endokrynologii i Chorób Metabolicznych, Instytutu Centrum Zdrowia Matki Polki, Lodz. Czech Republic: Prof, Jan Lebl, FN Motol, Prague; Dr. David Neumann, University hospital Hradec Králové, Hradec Králové; Dr. Jaroslav Skvor, Masarykova nemocnice v Ústí nad Labem, Ústí nad Labem. Hungary: Dr. Tamás Niederland, Petz Aladár Hospital, Gyor; Dr. Andrea Almási, BAZ Megyei Kórház, Miskolc; Dr. Ágota Muzsnai, Children hospital of Buda, Budapest. Prof. György Fekete, Semmelweis University, Budapest; Dr. Balázs Gellén, Clinic of Paediatrics, Szeged. Romania: Prof. Dr. Corina Galesanu, Spitalul Clinic Judetean de Urgente "Sf.Spiridon", Iasi. Dr. Florentina Moldovanu, Institutul pentru Ocrotirea Mamei si Copilului "Alfred Russescu", Bucharest; Prof. Dr. Simona Fica, Spitalul Universitar de Urgenta Elias Clinica de Endocrinologie, Bucharest; Dr. Ileana Puiu, Spitalul Clinic Judetean de Urgenta Craiova/Pediatric department, Craiova; Dr. Victoria Cret, Spitalul Clinic de Urgenta pentru Copii/Pediatric department, Cluj-Napoca. Georgia: Dr. David Metreveli, David Metreveli Medical Centre, Tblisi.

Disclosures. Hans-Peter Schwarz has received fees from Sandoz $\mathrm{GmbH}$ as International Coordinating Investigator for the EP00-401 and EP00-402 studies. Mieczysław Walczak has received fees from Sandoz GmbH as the country coordinating investigator for Poland. Mieczyslaw Szalecki has received fees from Sandoz $\mathrm{GmbH}$ as a principal investigator. Heike Woehling is an employee of Sandoz. Ellen Schuck is an employee of Sandoz. Dorota Birkholz-Walerzak and Michaela Nanu have nothing to disclose. 


\section{Compliance with Ethics Guidelines. All} procedures followed were in accordance with the ethical standards of the responsible committee on human experimentation (institutional and national) and with the Helsinki Declaration of 1964, as revised in 2013. Informed consent was obtained from all patients for being included in the study.

Open Access. This article is distributed under the terms of the Creative Commons Attribution-NonCommercial 4.0 International License (http://creativecommons.org/licenses/ by-nc/4.0/), which permits any noncommercial use, distribution, and reproduction in any medium, provided you give appropriate credit to the original author(s) and the source, provide a link to the Creative Commons license, and indicate if changes were made.

\section{REFERENCES}

1. Omnitrope ${ }^{\circledR}$ European Public Assessment Report 2008. Available from: http://www.ema.europa.eu/docs/en GB/document_library/EPAR_-_Scientific_Discussion/ human/000607/WC500043692.pdf. Accessed Feb 12, 2016.

2. Omnitrope ${ }^{\circledR}$ summary of product characteristics 2008 . Available from: http://www.ema.europa.eu/docs/en_ GB/document_library/EPAR_-_Product_Information/ human/000607/WC500043695.pdf. Accessed Feb 12, 2016.

3. Saenger P, Czernichow P, Hughes I, Reiter EO. Small for gestational age: short stature and beyond. Endocr Rev. 2007;28:219-51.

4. Clayton PE, Cianfarani S, Czernichow P, Johannsson G, Rapaport R, Rogol A. Management of the child born small for gestational age through to adulthood: a consensus statement of the International Societies of Pediatric Endocrinology and the Growth Hormone Research Society. J Clin Endocrinol Metab. 2007;92:804-10.

5. Boguszewski MC, de Zegher F, Albertsson-Wikland K. Serum leptin in short children born small for gestational age: dose-dependent effect of growth hormone treatment. Horm Res. 2000;54:120-5.

6. Barker DJ, Bull AR, Osmond C, Simmonds SJ. Fetal and placental size and risk of hypertension in adult life. BMJ. 1990;301:259-62.

7. Barker DJ, Gluckman PD, Godfrey KM, et al. Fetal nutrition and cardiovascular disease in adult life. Lancet. 1993;341:938-41.

8. Bhargava SK, Sachdev HS, Fall CH, et al. Relation of serial changes in childhood body-mass index to impaired glucose tolerance in young adulthood. N Engl J Med. 2004;350:865-75.

9. Eriksson JG, Osmond C, Kajantie E, Forsén TJ, Barker DJ. Patterns of growth among children who later develop type 2 diabetes or its risk factors. Diabetologia. 2006;49:2853-8.

10. Schwarz HP, Birkholz-Walerzak D, Szalecki M, et al. One-year data from a long-term phase IV study of recombinant human growth hormone in short children born small for gestational age. Biol Ther. 2014;4:1-13.

11. Niklasson A, Albertsson-Wikland K. Continuous growth reference from 24 th week of gestation to 24 months by gender. BMC Pediatr. 2008;8:8.

12. Elmlinger MW, Kühnel W, Weber MM, Ranke MB. Reference ranges for two automated chemiluminescent assays for serum insulin-like growth factor (IGF-I) and IGF binding protein-3 (IGFBP-3). Clin Chem Lab Med. 2004;42:654-64.

13. Jung H, Rosilio M, Blum WF, Drop SL. Growth hormone treatment for short stature in children born small for gestational age. Adv Ther. 2008;25:951-78.

14. Cutfield WS, Lindberg A, Rapaport R, Wajnrajch MP, Saenger P. Safety of growth hormone treatment in children born small for gestational age: the US trial and KIGS analysis. Horm Res. 2006;65(Suppl 3):153-9.

15. Lebl J, Lebenthal Y, Kolouskova S, et al. Metabolic impact of growth hormone treatment in short children born small for gestational age. Horm Res Paediatr. 2011;142:113-6.

16. Cutfield WS, Jackson WE, Jefferies C, et al. Reduced insulin sensitivity during growth hormone therapy for short children born small for gestational age. J Pediatr. 2003;142:113-6.

17. Kappelgaard AM, Kiyomi F, Horikawa R, et al. The impact of long-term growth hormone treatment on 
metabolic parameters in Japanese patients with short stature born small for gestational age. Horm Res Paediatr. 2014;81:272-9.

18. Romer T, Saenger P, Peter F, et al. Seven years of safety and efficacy of the recombinant human growth hormone Omnitrope ${ }^{\circledR}$ in the treatment of growth hormone deficient children: results of a phase III study. Horm Res. 2009;72:359-69.
19. López-Siguero J, Borrás Pérez MV, Balser S, Khan-Boluki J. Long-term safety and efficacy of the recombinant human growth hormone Omnitrope $^{\circledR}$ in the treatment of Spanish growth hormone deficient children: results of a phase III study. Adv Ther. 2011;28:879-93. 